\title{
ENGLISH REMEDIAL INSTRUCTION TO ENHANCE LOW-ACHIEVING STUDENTS' VOCABULARY
}

\author{
Jia-Yiing Ho \\ Universiti Pendidikan Sultan Idris and SMK Kapit \\ Sarawak \\ hojiayiing@outlook.com
}

\begin{abstract}
This study examines the extent to which using an English Remedial Instruction Course enhances the vocabulary of Form 3 Malaysian students at a rural school in Sarawak, Malaysia. The research questions addressed were: (1) What are the teachers' beliefs, assumptions and knowledge (BAK) in regards to teaching remedial students?; (2) Is there a significant difference in vocabulary competency between pre- and post-test mean score for those who underwent the English remedial instruction course in an ESL classroom and the control group?; and (3) What are the students' feedback regarding the use of remedial instruction in their ESL classroom? The vocabulary chosen for the study was taken from the Ministry of Education Malaysia Form 3 English Textbook Word List, mostly consisting of the common words used in the students' daily lives. An 8-week remedial instruction course which employed a variety of teaching theory-based activities was designed as the intervention process for the study. Thirty students (experimental group) were chosen from an English language Form 3 low-achieving class to undergo the course while another 30 students (controlled group) underwent the traditional chalk-andtalk and memorisation learning method. Pre-test and post-test statistical results of the students showed there were significant differences using Remedial Instruction enhance the learners' vocabulary. Learners' perceptions regarding the English Remedial Instruction course yielded positive responses as gathered through the feedback survey. Educational policy makers could thus improvise workshops and seminars based on these data-proven remedial instruction activities.
\end{abstract}

Keywords: English, remedial, instruction, vocabulary, beliefs, assumptions and knowledge

\section{Introduction}

According to McKay (2009), English language is now a global lingua franca. Possessing adequate proficiency in English is not only a basic requirement to secure careers or job promotions, it also enables an individual to obtain the latest 
knowledge and expand horizons. The importance of English has received great attention from the government of Malaysia and a variety of programmes have been carried out to enhance students' English proficiency, especially secondary school students. One of the main goals in the "Malaysia Education Blueprint (2013-2025)" issued by the Ministry of Education is to equip our students holistically to allow them to succeed in the $21^{\text {st }}$ century, with all of the opportunities and challenges that this new era presents (Ministry of Education, 2012, p. 8). According to the prime minister of Malaysia, Dato' Sri Haji Mohammad Najib bin Tun Haji Abdul Razak, "it is our nation's target to rise from the bottom-third to the top-third of the countries in the international assessments in PISA and TIMSS in 15 years" (Mininstry of Education, 2012, p.9). The deputy Education Minister P. Kamalanathan stated that the government plans to make English a compulsory subject to pass in the Sijil Pelajaran Malaysia (SPM) examinations in 2016 (Rozana, 2015).

Therefore, heightening students' motivation to learn English is a great challenge to most English teachers, especially those serving in rural schools of Sarawak, Malaysia. This is because the majority of the students in these rural schools come from longhouses, where the exposure to English language is limited.

\section{Background of Study}

In Malaysia, English is an important language and it is recognised as a second language in the country. Ibrahim and Mat Saman (2010) stated that English has been widely utilised as a means of interaction in various fields particularly education. The challenges that second language learners face in their lower secondary school years and upon entering the upper form are enormous, specifically when the language of instruction is not their first language. The vocabulary competency, in particular, represents a main concern for many low-achieving students who are expected to achieve the minimal Band 1 of the Form 3 English Language School Based Assessment. In a survey of 100 teachers in Malaysia, there appeared to be general consensus that the majority of low-achieving students lack interest in learning and they do not understand what is being taught. These Form 3 low-achieving students have a limited range of vocabulary; thus their motivation to learn is lower. Therefore, the probability of passing the PT3 seems to be very low, which would reflect negatively on the school's overall English subject academic performance and this causes great anxiety to the low-achieving students. This study serves to showcase the potential positive impacts of changing teaching methodologies to enhance students' vocabulary competency.

The Remedial Education Program is an instructional program designed for children who have identified deficiencies in reading, writing and mathematics (Richards, 2015). Remedial Instruction equips teachers with in-demand skills and addresses a very deep need within our education system. The remedial instruction activities are simple, yet significant and do not require an excessive amount of preparation. Furthermore, the approaches, pedagogies and activities that are related to remedial instruction are suitable for the level of the remedial students. Among the teaching theories incorporated in remedial instruction are Stephen Krashen's (1989) Affective Filter Hypothesis, Howard Gardner's (2011) Multiple 
Intelligence, Total Physical Response (Asher, 1969), Task-Based Approach (Ellis, 2004) and Language Experience Approach (Allen, 1970). Among the more distinct Multiple Intelligences incorporated in the remedial instruction course are interpersonal, musical and bodily kinesthetic skills. As for Task-Based Approach, students are grouped in the four to carry out most of tasks in the remedial instruction course. Each member will have a role, be it the scripter or the leader. Teacher brings students out of the classroom to experience the fun of learning English through the Language Experience Approach. Students are able to relate their daily occurrence to English language. The main motivation of this research is to investigate the effectiveness of the remedial activities, learning material and worksheet used during the remedial instruction course.

\section{Purpose of Study}

As discussed earlier, the low-achieving students of a rural secondary school in Sarawak face many vocabulary challenges in the usual one-size-fits-all learning environment. With the abundance of information and educational methodologies available, adapting the methods of teaching is appropriate since remedial instruction allows more individualised and modeled learning. The introduction of the English Remedial Instruction initiated by Malaysian English Language Teaching Centre is part of the initiative by Professional Learning Community under the Malaysia Education Blueprint (2013-2025). The remedial instruction course aims to transform the learning experience of remedial students and enable them to have a sense of achievement while allowing these learners freedom in relation to time and content. It is believed to empower remedial students with the motivation and vocabulary competency needed to enrich their learning experience. The remedial instruction does not aim to replace existing student-centered methods. It, however, attempts to provide English language teachers with an alternative approach to teaching English vocabulary in ESL classrooms. It aims at heightening the motivation of lowachieving learners and further engage these learners in the remedial instruction activities, thus fostering more learner autonomy.

The objective of the research is to determine the effectiveness of using RI to enhance low-achieving students' vocabulary. Based on the objective of this study, three research questions are addressed:

1) What are the teachers' beliefs, assumptions and knowledge (BAK) in regards to teaching remedial students?

2) Is there a significant difference in vocabulary competency between pre- and post-test mean score for those who underwent the English remedial instruction course in an ESL classroom and the control group?

3) What are the students' feedback regarding the use of remedial instruction in their ESL classroom? 


\section{Methodology}

The participants in this study consisted of two categories, 100 teachers serving in Malaysia and 60 Form 3 remedial students ( 24 male and 36 female) from a rural secondary public school which is only accessible via a 3-hour express boat ride in Sarawak. Almost half (49\%) of the teachers had three to 10 years of teaching experience.

For the first research question, "What are the teachers' beliefs, assumptions and knowledge (BAK) in regards to teaching remedial students?", an online survey consisting 10 questions (refer to Appendix A) were sent to teachers in Malaysia via the social media, Facebook. The Survey Monkey (SM) software was used to design the online survey and the data gathered were analyzed in the form of graphs and statistics.

To answer the second research question, "Is there a significant difference in vocabulary competency between pretest and posttest mean score for those who underwent the English remedial instruction course in an ESL classroom and the control group?", 30 of the 60 students were selected as the experimental group where they were exposed to Remedial Instructions course for eight weeks. The other 30 students were the control group who learned vocabulary through the traditional method of chalk-and-talk. An English remedial instruction course was adapted (see Appendix B) to suit the learners' needs by incorporating theories like Multiple Intelligences, Affective Filter Hypothesis, Task Based Approach, Total Physical Response and Language Experience Approach. The focus was on improving students' competency in vocabulary. Pre-tests and post-tests (see Appendix C) on vocabulary were given and the same sets of questions were used in order to find out the improvement of students' performance. The vocabulary test was pilot tested on 15 students for validity and reliability purposes and minor modifications were made before allowing the control and experimental groups to sit for the test.

For the experimental group, students underwent the 8-week remedial instruction course three days a week, 70 minutes for two days and 35 minutes for the other day. The total instruction time was 20 hours and 40 minutes. The objectives, instructions to carry out the lessons, and suggested list of vocabulary were stated in the remedial instruction course outline.

For the third research question, "What are the students' feedback regarding the use of Remedial Instruction in their ESL classroom?" a questionnaire entitled 'Teachers' Beliefs towards Teaching Low-achieving Students' was formulated. The questionnaire consisted of 10 questions measured on a five point Likert-type Scale (see Appendix D) were distributed to the experimental group to explore the effectiveness of the remedial instruction course. The online questionnaire was pilot tested on 15 teachers from Kapit district before it was used for the actual study. 100 teachers in Malaysia voluntarily participated in this online survey. There were more female respondents (65.31\%) than male respondents (34.69\%).

This research was a single-phase, 8-week study, employing quantitative methods. A mix-typed survey instrument was used to analyse the teachers' beliefs, assumptions and knowledge towards teaching low-achieving students and a pre- 
post vocabulary test was carried out for the student-participants, followed with a Likert-type scale survey for the students' feedback.

\section{Results and Discussion}

\section{Teachers' Beliefs, Assumptions and Knowledge in regards to Teaching Remedial Students}

Based on Table 1, 74 respondents felt that teaching low-achieving students was challenging while 16 respondents felt that teaching this target group was enjoyable. Four respondents did not have any particular feelings towards teaching remedial students whereas the remaining six respondents differed in opinions. Among the six responses, three teachers expressed negative feelings on teaching low-achieving students. Some of the words they used were "frustrating", "stressful" and "challenging and heart-breaking" while the other two stated positively that it was "rewarding" and "enjoyable and challenging". The $6^{\text {th }}$ teacher was neutral, stating "depend on the (students') discipline too".

Table 1

Percentage of responses with highest percentage for teachers' beliefs, assumptions and knowledge

\begin{tabular}{|c|c|c|c|}
\hline Item & $\begin{array}{c}\text { Aspects of beliefs, assumptions and } \\
\text { knowledge }\end{array}$ & $\begin{array}{l}\text { Responses } \\
\text { with highest } \\
\text { percentage }\end{array}$ & $\begin{array}{c}\text { Percentage } \\
\text { (\%) }\end{array}$ \\
\hline 1 & $\begin{array}{l}\text { Feelings of teaching low-achieving } \\
\text { students }\end{array}$ & Challenging & 74.00 \\
\hline 2 & $\begin{array}{l}\text { Challenges faced in teaching low- } \\
\text { achieving students }\end{array}$ & $\begin{array}{l}\text { Students are } \\
\text { not interested } \\
\text { in learning }\end{array}$ & 79.00 \\
\hline 3 & Belief that learning should be fun & Strongly agree & 56.00 \\
\hline 4 & $\begin{array}{l}\text { Belief that learners have different } \\
\text { learning styles }\end{array}$ & Strongly agree & 54.00 \\
\hline 5 & Belief that learning should be: & $\begin{array}{l}\text { learner } \\
\text { centered }\end{array}$ & 75.00 \\
\hline 6 & Belief that standardized tests are: & $\begin{array}{l}\text { doing more } \\
\text { good than } \\
\text { harm }\end{array}$ & 54.08 \\
\hline 7 & $\begin{array}{l}\text { Belief on teachers' patience and } \\
\text { students' motivation improve } \\
\text { academic performance }\end{array}$ & Yes & 79.80 \\
\hline
\end{tabular}

In Item 2, respondents were given a choice to tick more than an answer. The biggest challenge faced by teachers in teaching low-achieving students was that students were not interested in learning, followed by students did not understand what was being taught. The other challenges faced were insufficient experience to 
attract students' attention in class (37\%), insufficient knowledge to prepare suitable teaching materials (28\%), and insufficient time to prepare teaching materials (25\%). On the other hand, $7 \%$ of the respondents did not feel challenged in teaching lowachieving students. The other 11 responses were as follows:

1. "Not enough time to deal with them (no streaming), they need perhaps "one-to-four" kind of attention."

2. "No self-motivation in learning. No basic foundation. Do not want to try."

3. "Students are all in different proficiency level."

4. "They do not feel that learning in school is useful for them.

5. A big gap of proficiency level among the low achievers."

6. "Parents don't really care about education of their children."

7. "Students low motivation and aspiration to study."

8. "Too lazy."

9. "Teachers don't know the right methods to motivate students who have low self-esteem."

10. "Too burden with other workload such as disciplinary work."

11. "The only aim for them (students) is getting married."

The results for Item 3 showed that most of the respondents agreed that learning should be fun; 56 respondents chose "strongly agree" and 33 respondents chose "agree" whereas 82 participants viewed learning as fun. Four respondents remained neutral and the remaining 14 respondents disagreed that learning is fun.

For Item 4, 93 respondents agreed that learners had different learning styles. Nonetheless, there are 7 respondents who strongly disagreed with this statement.

It was observed for Item 5, 75 respondents believed that teaching should be learner-centered while five respondents held the belief that teaching should be teacher-centered. On the other hand, the remaining 20 respondents believed that teaching should be a mixture of both teacher- and student-centered approaches.

For Item 6, the teachers were divided in their beliefs on whether standardised tests were doing more harm than good $(45.92 \%)$. Over half of the teachers believed otherwise (54.08\%). Two respondents skipped this question.

For Question 7, 79.80\% of 100 respondents agreed that as long as teachers were patient and students were motivated to study, these low-achieving students would improve academically. Nonetheless, there were $19.19 \%$ of the respondents who were half-hearted and $1.01 \%$ chose a definite "no". One participant did not answer this question.

The results on teachers' beliefs, assumptions and knowledge showed that a majority of the teachers are hopeful that low-achieving students can improve academically through remedial instruction. This is supported by Taylor (1992) who emphasised Language Experience Approach can help literacy learners such as remedial students to relate their experience to a teacher or aide, who can help to transcribe them. Remedial students will learn more effectively once their affective filters are lowered as they enjoy the activities that are achievable for them. It is the 
sense of achievement in the students that will indirectly motivate teachers to prepare more task-based and learner-centered activities.

From the results obtained from the online surveys with teachers, it is possible to deduce that low-achieving students are equally important and should be not sidelined by teachers. Teachers play an important role in exploring various effective methodologies in engaging this group of learners in the classroom. Many teachers, especially the new and young teachers find teaching remedial students a great challenge and frustrating as they lack the patience and experience in teaching low-achieving students. This could be supported by Gardner's (2011) Multiple Intelligences theory in which every individual has their strength in different areas. As long as teachers can identify their students' strength, they can prepare lessons or activities which are engaging and effective for the low-achieving students. Van Uden, Ritzen and Pieters (2013) stated that student engagement is an important condition for positive outcomes at school. Van Uden et al's survey in Netherlands showed that teachers who rated themselves higher on self-efficacy, interpersonal teacher behavior and importance of pedagogical and didactic competence perceived their students as more engaged in learning.

Comparison Between the Pre- and Post-test Mean Scores of the Control and Experimental Groups of Students

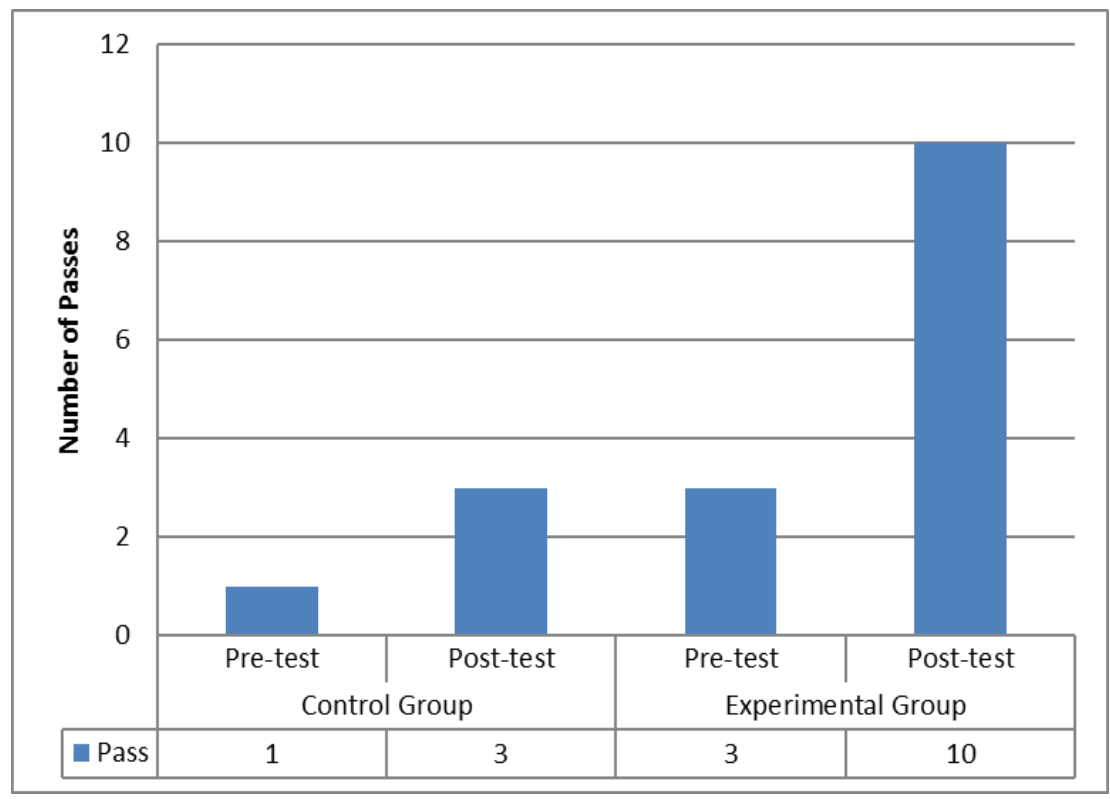

Figure 1. Comparison between students who passed the pre-test and post-test for the control and experimental group

The passing marks were set at $50 \%$. Based on Figure 1, there are more improvements in the post-tests as compared to their pre-tests for both control and experimental groups. One candidate passed in the pre-test for control group while there are three passes for the experimental group. In the post-test for the control 
group, three students from the control group passed but 10 from the experimental group passed. This shows that the treatment of remedial instruction is effective for the experimental group.

The findings of this study are compatible with the theoretical assumptions of cognitive language learning and the role of Task Based Language Learning in Second Language Acquisition (Saville-Troike, 2012). After analysing the 8-weeks remedial instruction vocabulary pre-test and post-test results, it is clear that the treatment performed better than the control group. The remedial instruction activities were engaging as every student in the class were involved in all the activities carried out. Students in the treatment group had to concentrate throughout the course as they could be randomly chosen by the teacher to answer questions. Furthermore, they would not want to disappoint their team members as group competitions encouraged positive competitions. In addition, the style of teaching based on RI encouraged the students to ask questions when they encountered difficulties or doubts in understanding the new vocabulary.

As stated in the research of Butler (2011), students learned most effectively when they were taught in a communicative setting. The improvement in the statistical results showed that remedial instruction, which was especially tailored for these remedial students, worked successfully for them as they felt a sense of achievement when they were able to complete a simple task which was within their capability. Hands-on activities were proven to be engaging as these weak learners had short attention span. Continual exposure which tapped their other multiple intelligences, such as kinesthetic intelligences, interpersonally intelligences and spatial-visual intelligences successfully attracted their interest in learning English. These arguments could be supported by Tomlinson (2011) and Gardner (2011) whose theories yielded positive results in incorporating task-based approach and tapping to students' multiple intelligences to enhance students' learning process. As emphasized in Krashen's (1989) Affective Filter hypothesis, when students' affective filters are lowered, learning takes place more easily.

\section{Experimental Group's Feedback on the Use of Remedial Instruction}

The survey results in Table 2 indicated that students showed positive responses with regards to the use of remedial instruction to enhance their vocabulary competence.

Based on Table 2, the activities that students liked in descending order of preference are games (86.7\%), acting and hands-on activities $(80 \%)$, pictures labelling (73.4\%), alphabets-stringing (66.7\%), flash cards (63.3\%), word-listing (60\%) and songs (46.7\%). The students did not like learning words using newspaper articles (40.1\%). Finally, since the class has a weak command of vocabulary and presumably also grammar, only $36.7 \%$ admitted that they could construct meaningful sentences. Thus, teachers can adopt the effective remedial instruction activities such as bingo and paper-scissor-stone games for their students as games and hands-on activities are perceived as more effective by the students.

Based on these results, it can be concluded that the low-achieving students learnt best when their affective filters were lowered. Without fear but eagerness in attempting more remedial instruction activities, these participants had overcome 
their ESL barrier and lowered their guard to allow learning to take place. Therefore, the data collected from the participants' feedback supported (1989) Affective Filter theory.

Table 2

Experimental group's feedback on the use of remedial instruction

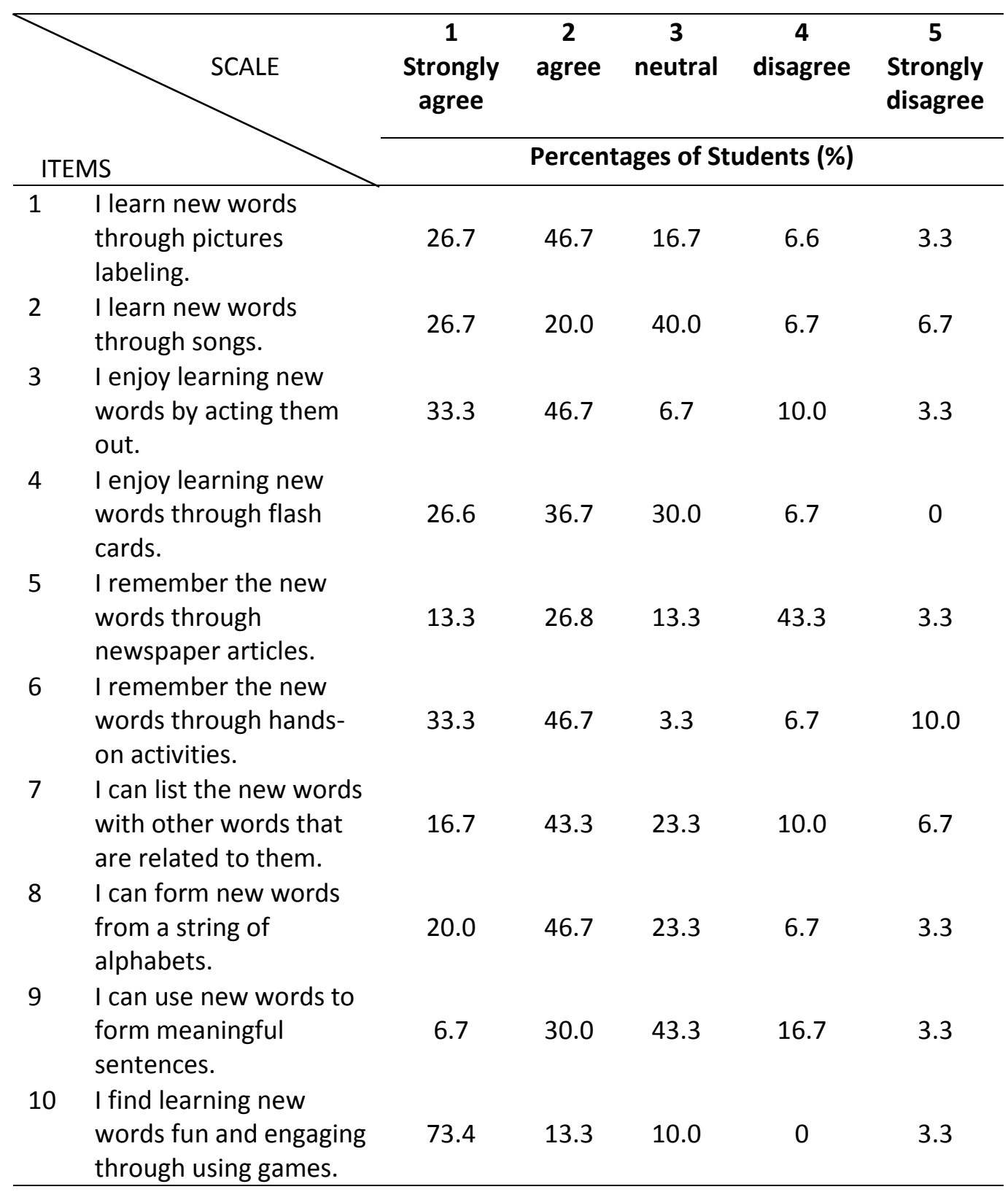

Constructing meaningful sentences and reading newspaper articles were least favored by the participants because those tasks were deemed more daunting as compared to fun-filled tasks like singing songs and playing games. This argument was supported by Tomlinson (2011) who highlighted the advantages of task-based 
approach in allowing learners to experience the language in ways used in the "real world" outside the classroom. As for acting out which was a form of Total Physical Response, Bowen (2013) stated that it is a teaching approach which is based, first and foremost, on listening and is linked to physical actions which are designed to reinforce comprehension of particular basic items. Therefore, when the lowachieving students could achieve the Task-Based Approach and Total Physical Response activities, they felt a sense of achievement and this eventually led them to lower down their affective filters. As proven by researchers on vocabulary learning by EFL secondary school learners, games are advantageous and effective in learning vocabulary (Aslanabadi, 2013). Thus, vocabulary games promote real world context into the ESL classroom, and this enhance the low-achieving students' vocabulary in a flexible and communicative way.

From the findings in the participants' feedback regarding the remedial instruction course, it could be inferred that there are some potential weaknesses inherent in it. Firstly, from a practical point of view, it is highly unlikely that even the most skilled and inventive teacher could sustain having lessons involving instructions, physical responses and outdoor experiences for more than a few lessons before the activity becomes repetitious for the learners, although the use of games could provide a range of contexts for practicing a wider range of lexis. Secondly, it is fairly difficult to manage the class once they are outside of the classroom, so the language input is basically restricted to those who stick close to the teacher. Thirdly, the relevance of some of the language used in remedial instruction activities to real-world learner needs is questionable. Finally, moving from remedial instruction games such as "Rock-Paper-Scissor" might be workable in a small group of remedial learners but it would appear to be problematic when applied to a class of 30 students, for example.

In defense of the remedial instruction course, however, it should be emphasised that it was never intended by Malaysia Ministry of Education that remedial instructions should extend beyond remedial students. In addition, a course designed around remedial instruction principles would not be expected to follow this remedial instruction course exclusively, and the researcher herself suggested that remedial instruction should be used in association with other methods and techniques. Short RI activities, used judiciously and integrated with other activities can be both motivating and linguistically purposeful. Careful choice of useful and communicative language at beginner level can make remedial instruction activities entirely valid. In terms of the theoretical basis for the approach, the idea of utilising the most effective activity that works for these remedial students resembles elements of Krashen's (1989) Natural Approach. Many learners respond well to kinesthetic activities and they can genuinely serve as a memory aid (Bowen, 2013). A lot of classroom warmers and games are based, consciously or unconsciously, on Task-Based Approach, Total Physical Response, and Language Experience Approach.

Based on the findings from students' responses on the questionnaire, it was found that a considerable number of participants felt more motivated because they experienced a greater sense of achievement and confidence during their English lessons. Learner autonomy is best identified in students in their heightened confidence and active classroom participation. This finding was not reflected only 
through the questionnaire but also through their improved results, and it is found to be consistent with Holec (1981) and Smith (1995) who place learners in the centre of their learning, which is enhanced by the English remedial instruction. Past research (Leake \& Lesik, 2007) holds that learners today highly appreciate task-based activities, and this remedial instruction in general increases student-centeredness, motivation, confidence and vocabulary enhancement.

\section{Conclusion}

In Malaysia, Professional Learning Community is actively carried out throughout the schools in Malaysia, with remedial instruction being a small yet significant program which caters especially to low-achieving students. With the mounting pressures for teachers to increase the school's overall academic performance, the remedial instruction course has emerged as an effective tool especially for rural schools where English is seen as a foreign language. The present study showed that remedial instruction improved the low-achieving students' vocabulary competency during the 8 -week study. Future research can conduct remedial instruction over a longer period of time to study its effects.

Insights gained through this study will provide educational leaders with quantitative data regarding educators' beliefs, assumptions and knowledge of educators and the results of the pre-test and post-test can assist in providing a quantitative view of the importance of implementing this course to more schools, which, ultimately, influences students' learning outcomes. Furthermore, these results may change the manner in which changes are implemented at the district and state levels.

The results of this research have implications for those at the federal government, state and district levels who are looking at the remedial instruction model as one to be adopted. Adopting one course over another might not be the proper way for schools to continue to grow with the challenges presented to educators to ensure the success and preparation of our remedial students. It is suggested that individuals at the state and district levels utilise theory and datadriven research results before advocating for one individual approach. Schools are continually faced with increased accountability as seen within high-stakes testing, as well as the push for increased academic performance. To accomplish these extremely difficult tasks, schools which consist of remedial students need to be provided with the proper tools and an effective program that will efficiently meet these needs. The findings from this study could prove beneficial in developing talking points that will allow policy makers to understand how to present trainings, workshops, as well as to search for opportunities to combine data-proven programs to create one that truly engages learners' interest and motivation which in the long run, will promote autonomous learners among these remedial groups.

\section{References}

Allen, V.R. (1970) Updating the Language Experience Approach. Retrieved from http://files.eric.ed.gov/fulltext/ED040831.pdf 
Asher, J. J. (1969). The Total Physical Response Approach to second language learning. The Modern Language Journal, 53(1), 3-17.

Aslanabadi, H., \& Rasouli, G. (2013). The effect of games on improvement of Iranian EFL vocabulary knowledge in kindergartens. International Review of Social Sciences and Humanities, 6(1), 186-195.

Bowen, T. (2013). Teaching approaches: Total physical response. Retrieved from http://www.onestopenglish.com

Butler, Y. G. (2011). The implementation of communicative and task-based language teaching in the Asia-Pacific region. Annual Review of Applied Linguistics, 31, 36-57.

Ellis, R. (2004). The methodology of task-based teaching. Educational Foreign Language Research, 79.

Gardner, H. (2011). Frames of mind: The theory of multiple intelligences ( $3^{\text {rd }}$ ed.). New York, NY: Basic Books.

Holec, H. (1981). Autonomy and Foreign Language Learning. Oxford: Pergamon.

Ibrahim, N. A., \& Mat Saman, N. (2010). A study of the cognitive reading strategies employed by ESL readers. Unpublished article, Faculty of Education, Universiti Teknologi Malaysia.

Leake, M., \& Lesik, S. A. (2007). Do remedial English programs impact first-year success in college? An illustration of the regression-discontinuity design. International Journal of Research \& Method in Education, 30(1), 89-99.

McKay, S.L. (2009). Teaching English as an international language: rethinking goals and approaches. Oxford: Oxford University Press.

Ministry of Education (2012). Malaysia Education Blueprint 2013-2025 (Preliminary Report). Retrieved from Ministry of Education website: http://www.moe.gov.my/userfiles/file/PPP/Preliminary-Blueprint-Eng.pdf

Rozana, S. (2015). Room for improvement. Retrieved from http://www.nst.com.my/news/2015/12/116794/room-improvement

Richards, W. (2015). Remedial Instruction Program. Georgia's School Superintendent.

Saville-Troike, M. (2012). Introducing second language acquisition. Cambridge: Cambridge University Press.

Smith, L. (1995). English in Education. English in Education, 29(2), 1-57.

Taylor, M. (1992). The Language Experience Approach and adult learners. Center for Applied Linguistics. Retrieved from http://www.cal.org/caela/esl_resources/digests/LEA.html

Thornbury, S. (2004). How to teach vocabulary. Essex: Pearson Education Limited.

Tomlinson, B. (2006). Materials development in language teaching. Cambridge: Cambridge University Press.

Van Uden, J. M., Ritzen, H., \& Pieters, J. M. (2013). I think I can engage my students. Teachers' perceptions of student engagement and their beliefs about being a teacher. Teaching and Teacher Education, 32, 43-54. doi: 10.1016/j.tate.2013.01.004 
APPENDIX A

\section{Survey Questionnaire}

Malaysian Teacher's Belief Towards Teaching Low-Achieving Students
1. Gender
Female
Male

\section{Teaching location}

Urban school in East Malaysia

Rural school in East Malaysia

Urban school in West Malaysia

Rural school in West Malaysia

Other (please specify)

\section{Years of teaching}
Less than 3 years
$3-10$ years
11 - 20 years
21 years and above

4. I feel that teaching low-achieving students is

Enjoyable

Challenging

No particular feelings

Other (please specify)

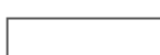

5. Select the challenges faced in teaching low-achieving students:
Students are not interested in learning
- Students do not understand what I taught
Insufficient time to prepare teaching materials
Insufficient knowledge to prepare suitable teaching materials
- Insufficient experience to attract students' attention in class
— I am not challenged in teaching low-achieving students
$\square$ Other (please specify) 
6. I believe that learning should be fun.

7. I believe that learners have different learning styles.

\section{I believe that teaching should be}

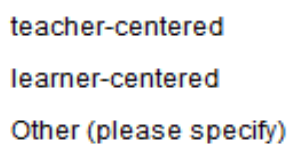

9. I believe that standardized tests are

doing more harm than good

doing more good than harm

10. I believe that as long as teachers are patient and these student are motivated to study, these low-achieving students will improve academically.
Yes
Maybe
No

Link to the survey:

https://www.surveymonkey.com/create/survey/preview?sm=t0IcP7LLZR9yMajF2Yzi 59fYs8mbgl7P70VNQzMJuDPTcQyHmBrTfs_2BwstKqnwlOk8wB9vFnG1QZ5w0u6xCu Iw_3D_3D 


\section{APPENDIX B}

\section{English Remedial Instructions Course Outline}

The aim of this English remedial instructions course is to enhance low-achieving students' vocabulary. The theories that lie behind this course are Task Based Approach, Total Physical Response and Language Experience Approach. The timetable, topics and objectives for the course are stated as shown below.

\begin{tabular}{|l|l|l|l|}
\hline Week and time & $\begin{array}{l}\text { Task-based } \\
\text { Approach }\end{array}$ & $\begin{array}{l}\text { Total Physical } \\
\text { Response }\end{array}$ & $\begin{array}{l}\text { Language } \\
\text { Experience } \\
\text { Approach }\end{array}$ \\
\hline Week 1 & $\begin{array}{l}\text { Label Things in the } \\
\text { Classroom }\end{array}$ & $\begin{array}{l}\text { Rock-Paper-Scissor } \\
\text { (High Frequency } \\
\text { Words }\end{array}$ & Out in the Sun \\
\hline Week 2 & $\begin{array}{l}\text { Newspaper Hunt } \\
\text { (Common Nouns) }\end{array}$ & $\begin{array}{l}\text { Bingo } \\
\text { (Synonyms) }\end{array}$ & $\begin{array}{l}\text { Language Learning } \\
\text { Diary } \\
\text { (Computer } \\
\text { laboratory) }\end{array}$ \\
\hline Week 3 & $\begin{array}{l}\text { Newspaper Hunt } \\
\text { (Proper Nouns) }\end{array}$ & $\begin{array}{l}\text { Simon Says } \\
\text { (Instructions) }\end{array}$ & $\begin{array}{l}\text { See-Draw-Write } \\
\text { (Garden) }\end{array}$ \\
\hline Week 4 & $\begin{array}{l}\text { Picture Collage } \\
\text { (Related words) }\end{array}$ & $\begin{array}{l}\text { Describe Me! } \\
\text { (Adjectives) }\end{array}$ & $\begin{array}{l}\text { Language Learning } \\
\text { Diary } \\
\text { (Library) }\end{array}$ \\
\hline Week 5 & $\begin{array}{l}\text { Action Words } \\
\text { (Pictures) }\end{array}$ & $\begin{array}{l}\text { Sing Along } \\
\text { (When I was Your } \\
\text { Man) }\end{array}$ & $\begin{array}{l}\text { Decorating Stones } \\
\text { (Suffixes } \\
\text { Prefixes) }\end{array}$ \\
\hline Week 6 & $\begin{array}{l}\text { Newspaper Hunt } \\
\text { (Verbs) }\end{array}$ & $\begin{array}{l}\text { Running Dictation } \\
\text { (Synonyms) }\end{array}$ & $\begin{array}{l}\text { Language Learning } \\
\text { Diary } \\
\text { (Synonyms) }\end{array}$ \\
\hline Week 7 & $\begin{array}{l}\text { Bingo } \\
\text { (Adjectives) }\end{array}$ & $\begin{array}{l}\text { Rock-Paper-Scissor } \\
\text { (High Frequency } \\
\text { Words) }\end{array}$ & $\begin{array}{l}\text { Out in the Sun } \\
\text { (Making } \\
\text { sentences) }\end{array}$ \\
\hline Week 8 & $\begin{array}{l}\text { Vocabulary Box } \\
\text { (Revising) }\end{array}$ & $\begin{array}{l}\text { Sing Along } \\
\text { (Just Give Me a } \\
\text { Reason) }\end{array}$ & $\begin{array}{l}\text { Language Learning } \\
\text { Diary } \\
\text { (Summing up) }\end{array}$ \\
\hline
\end{tabular}




\section{APPENDIX C}

\section{RI Pre-Post Test on Vocabulary Skills}

\section{A Sample of the Pre-Post Test on Vocabulary Skills}

\section{Instructions:}

This is a pre-post test on vocabulary skills. It was designed to assess your ability to use some vocabulary skills. It consists of five parts. The maximum score on the test is 100. The time allotted for answering the test questions is one hour.

Note: The vocabulary used here are the commonly used in Form 3 English textbook.

Name:

\section{Task 1 (20 marks)}

Circle the odd word in the following groups.

Example: water

$$
\text { soil }
$$

1. legs

2. Iorry

3. inside

4. pink

5. tooth

6. laugh

7. disappear

8. tomorrow

9. down

10. here

11. arms

12. skips

13. ponder

14. delicious

15. winter

16. storm

17. seas

18. brown

19. tree

20. love

$\begin{array}{ll}\text { eyes } & \text { ears } \\ \text { tired } & \text { car } \\ \text { under } & \text { sad } \\ \text { red } & \text { blue } \\ \text { finger } & \text { toe } \\ \text { live } & \text { smile } \\ \text { appear } & \text { missing } \\ \text { yesterday } & \text { fortnight } \\ \text { up } & \text { left } \\ \text { there } & \text { under } \\ \text { shoulders } & \text { elbow } \\ \text { beats } & \text { runs } \\ \text { wonder } & \text { think } \\ \text { scrumptious } & \text { delirious } \\ & \\ \text { summer } & \text { autumn } \\ \text { garden } & \text { lightning } \\ \text { oceans } & \text { sky } \\ \text { pink } & \text { coffee } \\ \text { enjoy } & \text { flower } \\ \text { water } & \text { milk }\end{array}$

sun

Score:

$\begin{array}{ll}\text { hands } & \text { joy } \\ \text { aeroplane } & \text { bicycle } \\ \text { on } & \text { in } \\ \text { cry } & \text { black } \\ \text { hair } & \text { truth } \\ \text { joke } & \text { amuse } \\ \text { lost } & \text { vanish } \\ \text { fortress } & \text { annually } \\ \text { right } & \text { weary } \\ \text { mountains } & \text { above } \\ \text { ankle } & \text { poverty } \\ \text { jumps } & \text { hunger } \\ \text { imagine } & \text { follow } \\ \text { yummy } & \text { mouth- } \\ & \text { watering } \\ \text { children } & \text { fall } \\ \text { thunder } & \text { flood } \\ \text { happiness } & \text { jungle } \\ \text { purple } & \text { red } \\ \text { leaves } & \text { plant } \\ \text { coffee } & \text { tea }\end{array}$




\section{Task 2 (20 marks)}

Circle the synonyms for the words below.

$\begin{array}{lllll}\text { 1. Achieve: } & \text { capture } & \text { brave } & \text { damage } & \text { accomplish } \\ \text { 2. Bravery: } & \text { explode } & \text { courage } & \text { polite } & \text { joy } \\ \text { 3. Choose: } & \text { enough } & \text { examine } & \text { select } & \text { challenge } \\ \text { 4. Dangerous: } & \text { cold } & \text { blame } & \text { interest } & \text { risky } \\ \text { 5. Essential: } & \text { famous } & \text { important } & \text { injure } & \text { clear } \\ \text { 6. Find: } & \text { discover } & \text { unite } & \text { often } & \text { argue } \\ \text { 7. Glad: } & \text { complain } & \text { fair } & \text { pleased } & \text { priceless } \\ \text { 8. Harm: } & \text { injure } & \text { isolated } & \text { interested } & \text { complete } \\ \text { 9. Immediately: deadly } & \text { faithful } & \text { instantly } & \text { retain } \\ \text { 10. Jealous: } & \text { wise } & \text { envious } & \text { generous } & \text { funny } \\ \text { 11. Knowledge: } & \text { study } & \text { wisdom } & \text { results } & \text { performance } \\ \text { 12. Legible: } & \text { clear } & \text { clever } & \text { potential } & \text { lawful } \\ \text { 13. Mistake: } & \text { correct } & \text { punish } & \text { error } & \text { forgive } \\ \text { 14. Necessary: } & \text { essential } & \text { abandon } & \text { discard } & \text { throw } \\ \text { 15. Often: } & \text { never } & \text { frequently } & \text { seldom } & \text { occasionally } \\ \text { 16. Purpose: } & \text { effect } & \text { impact } & \text { intention } & \text { result } \\ \text { 17. Quick: } & \text { stop } & \text { rapid } & \text { halt } & \text { odd } \\ \text { 18. } \text { Rescue: } & \text { save } & \text { steal } & \text { life } & \text { alive } \\ \text { 19. Sufficient: } & \text { lack } & \text { secure } & \text { enough } & \text { bare } \\ \text { 20. } \text { Trust: } & \text { lie } & \text { cheat } & \text { triumph } & \text { believe }\end{array}$

\section{Task 3 (15 marks)}

Complete the following table by selecting the antonyms of each word from the list.

$\begin{array}{lll}\text { Answer } & \text { Hungry } & \text { Mistake } \\ \text { Appear } & \text { Inside } & \text { Night } \\ \text { Beautiful } & \text { Laugh } & \text { Proud } \\ \text { Children } & \text { Love } & \text { Troubles } \\ \text { Darkness } & \text { Lie } & \text { Weary }\end{array}$

\begin{tabular}{|l|l|l|l|}
\hline Word & Antonym & Word & Antonym \\
\hline Eg: protect & harm & 8. energetic & \\
\hline 1. adult & & 9. full & \\
\hline 2. ashamed & & 10. hate & \\
\hline 3. blessings & & 11. light & \\
\hline 4. correct & & 12. outside & \\
\hline 5. cry & & 13. question & \\
\hline 6. day & & 14. truth & \\
\hline 7. disappear & & 15. ugly & \\
\hline
\end{tabular}


Task 4 (20 marks)

Form 20 words from this word worm.

\section{socialillslifechallengesdeterminationlove}

Example: people
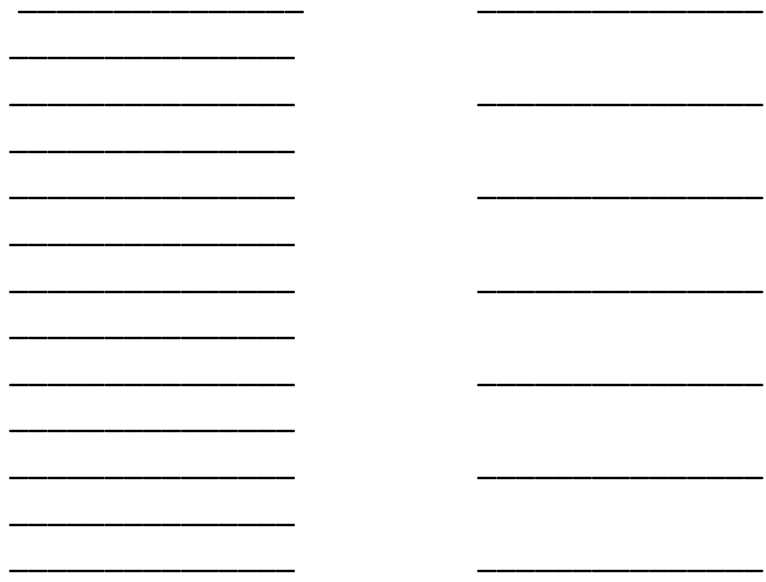

Task 5 (5 marks)

Choose 5 words from the choices below and construct meaningful sentences.

surprise children beautiful yesterday mountains

student generous station kind dreams

Example: surprise: She didn't give up to pursue her dreams of becoming a doctor.

1.

2.

3.

4.

5. 
Task 6 (20 marks)

Add the suitable prefix 'un-', 'non-', 'mis-' 'dis-', 'in-' 'pre-' or 'im-' and suffix 'able', '-ly', '-ness' or '-ion' to the words below to form new words.

\section{Eg: Possible : Impossible}

1. Agree :

2. Complete :

3. Alert :

4. Homesick :

5. Examine :

6. Understand :

7. Accidental :

8. Collect :

9. Definite :

10. Honest :

11. Comfort :

12. Grateful :

13. Polite :

14. Historical :

15. Afford:

16. Sufficient :

17. Red :

18. Satisfied :

19. Like :

20. Patient :

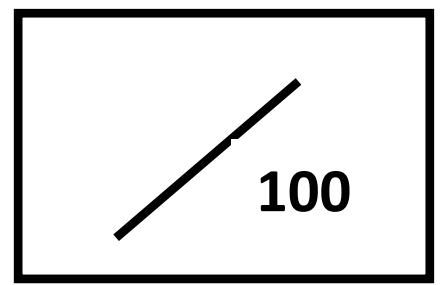




\section{APPENDIX D}

\section{Students' Feedback Questionnaire}

Survey of Using Remedial Instruction to Enhance Vocabulary Competence

The purpose of this survey is to find out more about yourself as a language learner and to help you discover ways by which you learn vocabulary. Identify the category that describes your use of each listed strategy. The categories are:

1. Strongly agree

2. Agree

3. Neutral

4. Disagree

5. Strongly disagree

$1 \quad$ l learn new words through pictures labeling.

$\begin{array}{lllll}1 & 2 & 3 & 4 & 5\end{array}$

I learn new words through songs.

3 I enjoy learning new words by acting them out.

$\begin{array}{lllll}1 & 2 & 3 & 4 & 5\end{array}$

$\begin{array}{lllll}1 & 2 & 3 & 4 & 5\end{array}$

4 I enjoy learning new words through flash cards.

$\begin{array}{lllll}1 & 2 & 3 & 4 & 5\end{array}$

5 I remember the new words through newspaper articles.

$\begin{array}{lllll}1 & 2 & 3 & 4 & 5\end{array}$

6 I remember the new words through hands-on activities.

$\begin{array}{lllll}1 & 2 & 3 & 4 & 5\end{array}$

$\begin{array}{llllllll}7 & \text { I can list the new words with other words that are related to } & 1 & 2 & 3 & 4 & 5\end{array}$ them.

8 I can form new words from a string of alphabets.

$\begin{array}{lllll}1 & 2 & 3 & 4 & 5\end{array}$

9 I can use new words to form meaningful sentences.

$\begin{array}{lllll}1 & 2 & 3 & 4 & 5\end{array}$

10 I find learning new words fun and engaging trough using $\begin{array}{llllll}1 & 2 & 3 & 4 & 5\end{array}$ games. 